Syntax Fusion : Jurnal Nasional Indonesia

p-ISSN: -

e-ISSN : $2775-4440$

Vol. 1, No. 8, Agustus 2021

\title{
PENGEMBANGAN MANAJEMEN SUMBER DAYA MANUSIA DALAM MENINGKATKAN MUTU LEMBAGA PENDIDIKAN BERBASIS TOTAL QUALITY MANAGEMENT
}

\author{
Mia Sari \\ Universitas Islam Negeri Sunan Kalijaga \\ e-mail: mia.sarii96@gmail.com
}

\begin{abstract}
Abstrak
Jurnal ini menyajikan tentang pengembangan manajemen sumber daya manusia dalam meningkatkan mutu lembaga pendidikan dasar dan menengah berbasis total quality management. Total quality management merupakan sebuah pendekatan praktis namun strategis, dalam menjalankan roda organisasi yang memfokuskan diri pada kebutuhan pelanggan dan kliennya. Tujuannya ialah untuk mencari hasil yang lebih baik dan konsistensi terhadap berbaikan yang berkelanjutan sehingga dapat meningkatkan kualitas lembaga pendidikan. Penelitian ini merupakan penelitian kepustakaan dengan menggunakan pendekatan kualitatif. Hasil dari penelitian ini menunjukan bahwa Implementasi total quality management dalam pengembangan sumber daya manusia sebagai upaya peningkatan kualitas mutu sangat diperlukan dalam sebuah lembaga pendidikan hal ini dikarenakan total quality management memiliki prinsip pada berbaikan yang berkelanjutan dan sumber daya manusia merupakan sebuah asset penting yang dimiliki oleh sebuah lembaga pendidikan sehingga harus dijaga dan dikembangkan dengan sebaik-baiknya agar sebuah lembaga dapat terus bertahan dalam menghadapi persaingan dan terus berkembang
\end{abstract}

Kata Kunci: Sumber daya manusia, total quality management, mutu pendidikan

\section{Pendahuluan}

Sumber daya manusia memiliki peran yang penting dalam mencapai kesuksesan suatu organisasi maupun lembaga pendidikan. Manusia memiliki peran aktif dan mendominasi dalam setiap kegiatan organisasi dikarenakan manusia sebagai perancang, pemeran dan penentu tercapainya tujuan organisasi (Melayu Sp. 2007). Sehingga suatu lembaga dapat dikatakan sukses apabila dapat mencapai tujuan dari organisasi maupun lembaga itu sendiri yang dapat dicapai jika kualitas sumber daya manusianya baik.

Untuk melahirkan sumber daya manusia yang berkualitas dibutuhkan upaya yang terorganisasi, berkesinambungan serta menyeluruh. Kualitas sumber daya manusia merupakan perpaduan antara kualitas fisik (kesehatan) dan kualitas non fisik (Nilam 
Sari, 2018). Sehingga untuk memperbaiki kulitas sumber daya manusia diperlukan upaya pemberdayaan dan pengembangan manajemen sumber daya manusia.

Pemberdayaan merupakan kemampuan yang lebih baik dari sebelumnya baik dalam hal kesanggupan (competency), wewenang (authority), tanggung jawab individual yang dimiliki seseorang (Sedarmayanti, 2001). Sedangkan pengembangan sumber daya manusia dapat dilihat dari dua aspek, yaitu kuantitas dan kualitas. Kuantitas ialah menyangkut jumlah sumber daya manusia dan kuantitas tanpa disertai dengan kualitas sumber daya manusia yang baik maka akan menjadi beban suatu perusahaan. Dalam hal ini maka suatu organisasi harus memperhatikan skills, knowledge, dan ability (SKA) atau kompetensi yang harus dipenuhi (Edy Sutrisno, 2010).

Pengembangan sumber daya manusia merupakan proses persiapan individu-individu untuk memikul tanggung jawab yang berbeda atau lebih tinggi di dalam organisasi, biasanya berkaitan dengan peningkatan kemampuan intelektual untuk melaksanakan pekerjaan yang lebih baik. Dalam hal ini pengembangan dipandang sebagai peningkatan kualitas sumber daya manusia dilakukan melalui program-program pelatihan, pendidikan. Pengembangan sumber daya manusia bertujuan untuk meingkatkan kualitas profesionalisme dan keterampilan para karyawan dalam melaksanakan tugas dan fungsinya secara optimal.

Manajemen sumber daya manusia bisa didefinisikan sebagai proses serta upaya untuk merektrut, mengembangkan, memotivasi, serta mengevaluasi keseluruhan sumber daya manusia yang diperlukan perusahaan dalam mencapai tujuannya (Fatahullah Jurdi, 2018). Sebuah lembaga pendidikan membutuhkan pengelolaan sumber daya manusia yang efektif dalam meningkatkan kinerjanya. Dalam upaya tersebut maka lembaga pendidikan harus memiliki sumber daya manusia untuk dapat bekerja secara optimal, sehingga perlu melakukan pengembangan sumber daya manusia agar memiliki sikap kreatif dan inovatif dalam menghadapi persaingan (W Walidin, 2016).

Dalam menghadapi persaingan di era sekarang semua lembaga pendidikan dituntut untuk terus meningkatkan mutu lembaga dengan upaya pengembangan sumber daya manusia yang berbasis total quality management. Hal ini dikarenakan misi utama dari sebuah institusi berbasis total qulity management adalah untuk memenuhi kebutuhan dan keinginan pelanggannya. Organisasi yang unggul, baik negeri maupun swasta adalah organisasi yang menjaga hubungan dengan pelanggannya dan memiliki obsesi terhadap mutu (Edward Sallis, 2012).

Pengembangan manajemen sumber daya manusia dalam rangka meningkatkan mutu pendidikan di lembaga pendidikan dasar dan menengah dirasa penting. Hal ini dikarenakan pendidikan dasar dan menengah memiliki peran sentral dan strategis dalam menunjang kelangsungan serta keberhasilan pendidikan pada jenjang yang lebih tinggi, serta pendidikan dasar termasuk program wajib belajar bagi penduduk Indonesia yang berada pada usia tersebut (Sudadio, 2012). Penelitian ini akan membahas lebih lanjut terkait pengembangan manajemen sumber daya manusia dalam 
meningkatkan mutu lembaga pendidikan dasar dan menengah berbasis total quality management.

\section{Metode Penelitian}

Bagian Penelitian ini merupakan penelitian kepustakaan (library research). Metode yang digunakan dalam penelitian ini ialah penelitian kualitatif. Penelitian kualitatif merupakan penelitian yang menggunakan pendekatan naturalistik untuk mencari dan menemukan pengertian atau pemahaman tentang fenomena dalam suatu latar yang berkonteks khusus (Sutrisno Hadi, 1994).

Partisipan atau sumber data yang digunakan dalam menyelesaikan penelitian kepustakaan ini berasal dari perpustakaan baik berupa buku, jurnal dan dokumen lainnya (Sutrisno Hadi, 1990). Sumber data primer merupakan buku yang ditulis oleh Edward Sallis, dan sumber data sekundernya berupa literatur jurnal.

Teknik analisis data yang digunakan dalam penelitian ini ialah analisis data flow model, Miles dan Hubberman menyebutkan dalam bukunya bahwa analisis Flow Model terdiri dari beberapa alur kegiatan yang terjadi dengan beberapa langkah analisis, yaitu pengumpulan data, reduksi data, penyajian data dan penarikan kesimpulan

\section{Hasil Dan Pembahasan}

\section{Pengembangan Manajemen Sumber Daya Manusia}

Terdapat beberapa hal yang menjadi sebab diperlukannya pengembangan manajemen sumber daya manusia dalam meningkatkan mutu lembaga pendidikan dasar dan menengah, yaitu standar sarana prasarana yang belum terpenuhi sehingga membuat proses pembelajaran kurang maksimal dikarenakan tenaga pendidik yang harus mengajar beberapa gelombang, waktu, kemudian masih terdapat guru yang hadir terlambat dan kurang disiplin, dan pemahaman tenaga pendidik terhadap kurikulum pembelajaran (Suparto, 2016).

Peningkatan sumber daya terhadap peningkatan mutu dan profesionalisme guru dan tenaga pendidikan juga merupakan prioritas utama dalam pembangunan pendidikan, karena tenaga pendidik (guru) merupakan salah satu elemen penting dalam system pendidikan, bahkan komponen-komponen lain tidak akan berarti banyak apabila guru dalam proses pembelajaran tidak mampu berinteraksi baik dengan peserta didik dan stakeholder dengan baik dan sempurna.

Sumber daya manusia dianggap sebagai salah satu faktor yang paling penting dalam memainkan peran utama dalam menjaga keberlanjutan organisasi maupun lembaga, kreadibilitas serta penciptaan kepercayaan publik (Roosje Kalangi, 2015). Hal ini dikarenakan keberhasilan dan ketercapaian tujuan pendidikan nasional tergantung pada sumber daya manusia yang ada di sekolah/ madrasah (H. Abd. Wahid Tahir, 2017).

Manajemen sumber daya manusia bisa didefinisikan sebagai proses serta upaya untuk merektrut, mengembangkan, memotivasi, serta mengevaluasi keseluruhan sumber daya manusia yang diperlukan perusahaan dalam mencapai 
tujuannya. Hal ini dikarenakan hakikat keberhasilan dan ketercapaian tujuan pendidikan nasional tergantung pada sumber daya manusia yang ada di lembaga pendidikan tersebut.

Islam telah mengajarkan kita untuk melakukan pengembangan terhadap sumber daya manusia melalui pelatihan terhadap para pegawai dengan tujuan untuk mengembangkan kompetensi dan kemampuan sehingga dapat menjalankan tanggung jawab pekerjaannya. Hal ini dikarenakan sumber daya manusia yang professional ialah sumber daya manusia yang kafa'ah (memiliki keahlian), amanah (terpercaya), himmatul amal (memiliki etos kerja yang tinggi). Maka pembinaan dan pengembangan yang mencakup tiga aspek diperlukan, yaitu syahsiyyahh islamiyah (kepribadian islam), skill (kemampuan dan keterampilan) dan kepemimpinan dan kerjasamanya dalam tim (H I Anwar, 2012).

Sumber daya manusia pada lembaga pendidikan yaitu mencakup tenaga pendidik (guru) dan tenaga kependidikan yang meliputi pegawai administrasi, laboran, putakawan, teknisi, serta pembantu pelaksana (tenaga kebersihan). Manajemen sumber daya manusia merupakan suatu proses perencanaan, pengorganisasian, pengarahan, dan pengawasan kegiatan-kegiatan pengadaan, pengembangan, pemberian kompensasi, pengintegrasian, pemeliharaan dan pelepasan sumber daya manusia agar tercapai berbagai tujuan individu, organisasi dan masyarakat (T Hani Handoko, 1996).

Perencanaan sumber daya manusia dapat dimulai melalui penilaian terhadap ketersediaan sumber daya manusia yang ada di suatu lembaga pendidikan secara menyeluruh yang dapat dilakukan dalam rapat pimpinan, kemudian rekrutmen sumber daya manusia yang ditujukan untuk mencari dan menarik pelamar yang memiliki komptensi dan skill sesuai posisi yang dibutuhkan oleh lembaga pendidikan tersebut. Selanjutnya yaitu pengembangan sumber daya manusia untuk meningkatkan kualitas sumber daya manusia.

Pengorganisasian (organizing) merupakan pengorganisasian terhadap sumber daya yang dimiliki oleh suatu lembaga/organisasi agar rencana pengelolaan dan pengembangan sumber daya manusia yang sudah dibuat dapat betul-betul dijalankan.

Sedangkan pengarahan menurut Hasibuan yang dikutip oleh Vika Luila dan Bambang Haryadi merupakan kegiatan mengarahkan semua pegawai maupun karyawan agar mau bekerja sama dan bekerja efektif serta efisien dalam membantu tercapainya tujuan lembaga maupun organisasi. Selanjutnya yaitu pengendalian adalah kegiatan mengendalikan semua pegawai dan karyawan agar menaati peraturan-peraturan perusahaan dan bekerja sesuai dengan rencana (Vika Laula dan Bambang Haryadi, 2013).

Sebuah lembaga pendidikan membutuhkan pengelolaan sumber daya manusia yang efektif dalam meningkatkan kinerjanya. Dalam upaya tersebut maka lembaga pendidikan harus memiliki sumber daya manusia untuk dapat bekerja secara optimal, sehingga perlu melakukan pengembangan sumber daya manusia agar memiliki sikap kreatif dan inovatif dalam menghadapi persaingan. 
Efisiensi dan efektivitas organisasi maupun lembaga pendidikan sangat tergantung pada baik buruknya pengembangan sumber daya manusia atau anggota dalam lembaga itu sendiri. Ini berarti bahwa sumber daya manusia yang ada dalam organisasi maupun lembaga pendidikan secara proporsional harus diperikan pelatihan dan pendidikan yang sebaik-baiknya, bahkan sesempurna mungkin (Muhammad Darari, 2011).

Dalam meningkatkan sumber daya manusia diperlukan pengembangan dan pelatihan sumber daya manusia ada beberapa langkah, yaitu: penentuan kebutuhan, penentuan sasaran, penetapan isi program, identifikasi prinsip-prinsip belajar, pelaksanaan program, identifikasi manfaat dan penilaian pelaksanaan program (Sondang P Siagan, 2016).

Pengembangan sumber daya manusia secara makro merupakan suatu proses peningkatan kualitas atau kemampuan manusia dalam rangka mencapai tujuan pembangunan bangsa yang mencakup perencanaan, pengembangan, dan pengelolaan. Sedangkan pengembangan sumber daya manusia secara mikro adalah suatu proses perencanaan pendidikan, pelatihan dan pengelolaan tenaga kerja atau karyawan untuk mencapai hasil yang optimal (Hendra Safri, 2016).

Pengembangan sumber daya manusia pada lembaga pendidikan mampu meningkatkan kontribusi sumber daya manusia terhadap organisasi atau lembaga dalam rangka mencapai produktivitas lembaga pendidikan (A Widiansyah, 2018). Pengelolaan sumber daya manusia yang tepat juga dapat mewujudkan tercapainya visi dan misi lembaga secara efektif dan efisien (Erlina Yuliyati, 2020).

Manajemen sumber daya manusia dalam meningkatkan kualitas lembaga pendidikan dapat dilakukan dengan beberapa hal, yaitu: perencanaan sumber daya manusia yang sesuai dengan kebutuhan yang ada di lembaga, rekrutment sumber daya manusia dan tenaga pendidik direkrut dengan melihat kemampuan yang dimiliki oleh pelamar dengan segala persyaratan yang dilakukan, seleksi dan penempatan sumber daya manusia seleksi yang diadakan di lembaga pendidikan dengan menentukan standar kelulusan pelamar, pelatihan dan pengembangan pelatihan dan pengembangan diikuti oleh guru dan tenaga kependidikan bersama dengan mengikuti seminar, workshop, MGMP maupun KKG yang ada di tingkat kecamatan atau kabupaten. Selanjutnya yaitu penilaian prestasi kerja penilaian difokuskan pada presensi/kehadiran dan kinerja antara lain berkaitan dengan keaktifan guru, ketepatan waktu dalam mengumpulkan tugas. Kemudian kesejahteraan pegawai (kompensasi) kesejahteraan dapat dikatakan berjalan baik yaitu memberikan apa yang menjadi hak guru dan staf administrasi yaitu berupa gaji, tunjangan berupa fungsional dan uang transport, kreatifitas guru dan intensif. Terakhir pemutusan hubungan kerja guru dan tenaga kependidikan lainnya diberhentikan sebab-sebab tertentu (Ika Dewi Rahmawati, 2012).

\section{Penerapan Total Quality Management dalam Meningkatkan Mutu Lembaga Pendidikan}

Total quality management (TQM) merupakan sebuah usaha yang dilakukan oleh suatu lembaga maupun organisasi untuk memberikan kepuasan terhadap pelanggan. 
Dengan adanya kepuasan pelanggan akan meningkatkan kepercayaan mereka dan akan berpengaruh terhadap tingginya minat pelanggan (Wali Saputra, 2014). TQM adalah sebuah pendekatan dalam upaya menjalankan usaha untuk menciptakan daya saing tinggi, yang dilakukan dengan system perbaikan secara terus-menerus atas jasa, proses, tenaga kerja dan produk.

Dalam sebuah organisasi yang menerapkan total quality management, pendidikan dan pelatihan merupakan faktor yang fundamental. Setiap orang diharapkan dan didorong untuk terus belajar, yang tidak ada akhirnya dan tidak mengenal batas usia. Dengan belajar, setiap orang dalam perusahaan dapat meningkatkan keterampilan teknis dan keahlian profesionalnya. Penerapan total quality management pada dasarnya dapat mempengaruhi secara supervisi sebagai bagian dari pelaksanaan monitoring terhadap pencapaian produktivitas dan kinerja karyawan (Desi Eka Kartika, 2018).

Total quality management dalam dunia pendidikan memiliki tujuan dalam peningkatan kualitas, daya saing bagi output (lulusan) dengan indikator adanya kompetensi baik intelektual maupun keterampilan serta kompetensi social siswa/lulusan yang tinggi. Dalam mencapai hal tersebut, impelemtasi total quality management di dalam lembaga pendidikan perlu dilakukan dengan sebaik-baiknya hal ini dikarenakan penerapan total quality management sebagai upaya peningkatan mutu pendidikan tidak dapat dicapai dengan cara instant.

Manajemen mutu pendidikan merupakan alternatif baru dalam pengelolaan pendidikan yang lebih menekankan kepada kemadirian dan kreativitas sekolah. Mutu merupakan keunggulan dari sebuah produk barang atau jasa yang dihasilkan melalui proses kerja yang telah terencana dengan baik. Mutu merupakan tujuan akhir dari sebuah proses panjang yang dilakukan oleh organisasi. Mutu merupakan jaminan dari sebuah lembaga terhadap pelanggannya (Fadriati, 2018).

Mutu proses pembelajaran mengandung makna bahwa kemampuan sumber daya sekolah mentransformasikan mutijenis masukan dan situasi untuk mencapai derajat nilai tambah tertentu dari peserta didik. Dalam bahasa lain proses pendidikan kejadian berubahnya sesuatu menjadi sesuatu yang lain. Dalam ranah pendidikan berskala mikro, proses yang dimaksud meliputi pengambilan keputusan, pengelolaan kelembagaan, pengelolaan program, kegiatan belajar mengajar serta monitoring dan evaluasi (Fitriani, 2017).

Mutu tidak lahir dan berdiri sendiri, melainkan melibatkan banyak faktor untuk keberadaannya. Adapun yang terlibat tersebut ialah system penjaminan mutu (quality assurance system). Sistem inilah yang akan mengawal mutu lembaga pendidikan. Dan sistem ini pulalah yang akan bertanggungjawab mendistribusikan ouput lembaga pendidikan (Khoirul Anwar, 2018). Pelaksanaan sistem penjaminan mutu pendidikan dasar dan menengah di Indonesia yaitu mengacu pada standar sesuai dengan peraturan pemerintah yang berlaku. Acuan utama system penjaminan mutu pendidikan dasar dan menengah adalah standar nasional pendidikan (SNP) yang ditetapkan oleh pemerintah pusat melalui Badan Standar Nasional Pendidikan (BNSP). SNP merupakan standar minimal yang ditetapkan pemerintah dalam bidang pendidikan yang harus dipenuhi oleh 
satuan pendidikan. Standar Nasional Pendidikan (SNP) itu sendiri terdiri dari delapan unsur, yaitu: standar kompetensi lulusan, standar isi, standar proses, standar penilaian, standar pendidik dan tenaga kependidikan, standar pengelolaan, standar sarana dan prasarana dan standar pembiayaan.

Mutu dapat dikatakan ada apabila sebuah layanan dapat memenuhi spesifikasi yang ada. Mutu merupakan sebuah cara yang menentukan apakah produk terakhir sesuai dengan standar ataupun belum (Enward Sallis, 2012). Manajemen mutu di lembaga pendidikan dapat dilakukan dengan cara mengatur semua sumber daya pendidikan, agar menjalankan tugas pokok dan fungsinya dengan penuh tanggung jawab, sehingga mampu menghasilkan jasa dan layanan berkualitas sesuai harapan dan kebutuhan user (Lilik Huriyah, 2016).

Total quality management merupakan suatu makna dan standar mutu dalam pendidikan. Ia memberikan suatu filosofi perangkat alat untuk memperbaiki mutu dan itu semua dapat dicapai dengan ide sentral yang diwujudkan dalam bentuk pelaksanaan. Manajemen mutu yang efisien dari suatu organisasi dicapai dengan menggunakan model yang berbeda. Salah satunya system manajemen mutu tersebut. Dengan manajemen mutu system dapat memahami struktur, prosedur, proses, dan sumber daya yang diperlukan lainnya yang diperlukan dalam penerapan manajemen mutu (Abdul Hadi, 2018).

Sebagaimana kita ketahui bahwa tujuan utama total quality management dalam pendidikan adalah meningkatkan mutu pendidikan secara terus-menerus, berkelanjutan, dan terpadu, sehingga dapat memuaskan pelanggan pendidikan. Upaya peningkatan mutu pendidikan yang dimaksudkan tidak sekaligus, tapi dituju berdasarkan peningkatan mutu pada setiap komponen pendidikan (Marno dan Triyo Supriyanto, 2008). Dalam hal ini termasuk manajemen sumber daya manusia dalam pendidikan salah satu komponen pendidikan sebagai upaya peningkatan kualitas mutu lembaga pendidikan.

Total quality management sebagai sebuah system mutu meniscayakan keterlibatan banyak stakeholders untuk mencapai tujuan dengan semangat kerja yang terus-menerus dan meningkatkan peran pimpinan dalam membangun suasana lembaga pendidikan yang memacu kinerja (Ahmad Darmadji, 2015).

Dalam peningkatan mutu pendidikan dapat dipengaruhi oleh faktor input pendidikan dan faktor proses manajemen pendidikan. Input pendidikan merupakan segala sesuatu yang harus tersedia karena dibutuhkan untuk berlangsungnya proses pendidikan. Input pendidikan terdiri dari seluruh sumber daya yang meliputi sumber daya manusia (man), dana (money), sarana prasarana (material) serta peraturan (Policy) (Soebagio Atmodiwirio, 2000).

Konsep total quality management ini tidak akan mencapai tujuannya apabila prinsip-prinsip dalam TQM sendiri tidak dipegang teguh. Karena TQM ini sangat berhubungan dengan integritas dan loyalitas karyawan, maka dalam jiwa pemimpinnya sampai tingkat karyawan paling bawah haruslah tertanam akan pentingnya mutu dan kualitas tugas mereka masing-masing (Midtakhul Munir, 2018). 
Kunci sukses kultur total quality management adalah mata rantai internaleksternal yang efektif antara pelanggan-produsen. Dalam konteks pendidikan, total quality management merubah pola hubungan dengan memberikan sebuah focus pelanggan yang jelas. Focus ini tidak berdampak pada struktur otoritas dalam sekolah maupun universitas, dan ia juga tidak mengurangi peran kepemimpinan manajer senior. Dan pada kenyataannya kepemimpinan juga sangat penting bagi kesuksesan total quality management.

Crosby dalam bukunya, quality is free menguraikan pendapatnya bahwa sebuah langkah sistematis untuk mewujudkan mutu akan menghasilkan mutu yang baik. Menurut Crosby ada beberapa langkah dalam sebuah program mutu, yaitu:

1. komitmen manajemen

2. membangun tim peningkatan mutu

3. pengukuran mutu

4. mengukur biaya mutu

5. membangun kesadaran mutu

6. kegiatan perbaikan

7. perencanaan tanpa cacat

8. pelatihan pengawas

9. menyelenggarakan hari tanpa cacat

10. penyusunan tujuan

11. penghapusan sebab kesalahan

12. pengakuan

13. mendirikan dewan-dewan mutu

14. lakukan lagi

Terdapat beberapa manfaat penerapan total quality management bagi institusi, yaitu sebagai berikut:

1. terdapat perubahan kualitas produk dan pelayanan

2. Staf lebih termotivasi

3. Produktivitas meningkat

4. Biaya turun

5. Produk cacat berkurang

6. Permasalahan dapat diselesaikan

Pengembangan manajemen sumber daya manusia dalam meningkatkan mutu lembaga pendidikan dasar dan menengah berbasis total quality management merupakan salah satu langkah yang perlu untuk dilaksanakan pada setiap lembaga. Dan mutu dikatakan ada apabila memenuhi spesifikasi standar mutu. Namun dalam pelaksanaan proses pembelajaran di tingkat dasar maupun menengah di setiap daerah masih belum merata dan ada belum maksimal.

Hal ini dikarenakan terdapat beberapa sekolah yang belum memenuhi standar mutu minimal yaitu standar nasional pendidikan (SNI). Dimana dalam suatu daerah masih belum tercukupinya sarana dan prasarana dan belum memenuhi standar sarana 
prasana yang membuat pembelajaran harus dibagi menjadi tiga waktu sehingga mengurangi kualitas pembelajaran yang disampaikan oleh tenaga pendidik karena faktor kenyamanan tempat belajar maupun faktor guru kelelahan mengajar siswa dalam tiga waktu belajar.

Kemudian untuk meningkatkan mutu lembaga pendidikan dapat kita lihat dari ouput dalam satu kurikulum pembelajaran yang sama ketika disampaikan oleh dua pengajar yang berbeda maka hasil yang diperoleh siswa pun akan berbeda maka pengembangan dan pelatihan terhadap sumber daya pendidik sangat perlu dilakukan.

Dalam dunia pendidikan, menjaga kualitas mutu merupakan hal yang sangat penting, tidak hanya menyangkut output akan tetapi lebih dari itu yaitu input, proses, output dan outcome. Input pendidikan yang bermutu ialah pendidik, karyawan, peserta didik, kurikulum, sarana prasarana serta aspek penyelenggara pendidikan yang lain. Proses pendidikan bermutu ialah proses pembelajaran dan penyelenggara pendidikan. Output yang bermutu ialah lulusan yang memiliki kompetensi yang dipersyaratkan. Dan outcome yang bermutu ialah lulusan yang melanjutkan ke pendidikan jenjang yang lebih tinggi.

Selanjutnya peningkatan mutu lembaga dan sumber daya manusia di era otonomi pendidikan ini dapat dilakukan melalui pendekatan makro dan mikro. Pendekatan makro dapat dikembangkan melalui penataan system birokrasi, adanya transparasi (keterbukaan), pemberdayaan SDM dosen/ guru dan staf (karyawan) dengan keunggulan konpetitif, optimalisasi jaringan, profesionalitas administrasi dan manajemen, penataan mutu input, proses, dan output, menjalin hubungan strategis dengan stakeholder (pemerintah dan swasta), mencari sumber-sumber termasuk sumber pembiayaan untuk memajukan lembaga (Rusmini, 2011).

Sedangkan pendekatan mikro dapat dilakukan melalui penataan mutu dosen/ guru dan pengembangan pendidikan yang berkarakter. Selain itu untuk meningkatkan lembaga tingkat perguruan tinggi juga dapat mengupayakan untuk pengembangkan jurusan-jurusan baru yang relevan dengan kebutuhan masyarakat dan lapangan kerja, serta relevan dengan kebutuhan pengembangan lembaga.

Pendekatan total quality management dalam pengembangan manajemen sumber daya manusia dapat dilaksanakan dari mulai perencanaan sumber daya manusia, rekrutmen sumber daya manusia dan pengembangan sumber daya manusia. Pengelolaan pendidikan dan pengembangan sumber daya manusia yang dilaksanakan secara professional demi terciptanya tujuan pendidikan nasional.

\section{Kesimpulan}

Penutup Implementasi total quality management dalam pengembangan sumber daya manusia sebagai upaya peningkatan kualitas mutu sangat diperlukan dalam sebuah lembaga pendidikan hal ini dikarenakan total quality management memiliki prinsip pada berbaikan yang berkelanjutan dan sumber daya manusia merupakan sebuah asset penting yang dimiliki oleh sebuah lembaga pendidikan sehingga harus dijaga dan 
dikembangkan dengan sebaik-baiknya agar sebuah lembaga dapat terus bertahan dalam menghadapi persaingan dan terus berkembang.

Konsep total quality management ini akan mencapai tujuan apabila dalam pelaksanaannya memegang teguh prinsip-prinsipnya. Adapun strategi dalam pendekatan total quality management pada pengembangan manajemen sumber daya manusia dapat dilaksanakan dari mulai perencanaan sumber daya manusia, rekrutmen sumber daya seleksi penempatan sumber daya manusia, pelatihan dan pengembangan, penilaian prestasi kerja, kesejahteraan pegawai (kompensasi) dan pemutusan hubungan kerja jika diperlukan.

Berdasarkan pemaparan diatas, penulis menyadari masih sangat banyak kekurangan dalam penelitian maupun penulisan serta masih kurang dalam mencari literature terkait manajemen sumber daya manusia dan total quality management. Penulis berharap untuk peneliti-peneliti yang akan datang untuk dapat menyempurnakan penelitian terkait pengembangan manajemen sumber daya manusia dalam meningkatkan mutu lembaga pendidikan dasar dan menengah berbasis total quality management. 


\section{Bibliografi}

Anwar, Khoirul, 'Peran Sistem Penjaminan Pendidikan Dalam Meningkatkan Mutu Pendidikan Di Madrasah', Jurnal Pendidikan Agama Islam, 1.1 (2018)

Atmodiwirio, Soebagio, Manajemen Pendidikan Indonesia, (Jakarta: Azdadizya Jaya, 2000)

Bariqi, Muhammad Darari, 'Pelatihan Dan Pengembangan Sumber Daya Manusia', Jurnal Studi Manajemen Dan Bisnis, 5.2

Desy Eka Kartika Sari, Surachman, Kusuma Ratnawati, 'Pengaruh Total Quality Management (TQM) Terhadap Kinerja Karyawan Dengan Mediasii Kepuasan Kerja', Jurnal Bisnis Dan Manajemen, 5.1

Endraswari, Lilik Huriyah dan, 'Penerapan Total Quality Management Dalam Peningkatan Mutu Layanan Publik UIN Sunan Ampel Surabaya', Journal of Islamic Studies, 1.2 e-ISSN 2541-173X. (2016)

Eric Alamzah Limawandoyo, dan Augustinus Simanjutak, 'Pengelolaam Dan Pengembangan Sumber Daya Manusia Pada PT. Aneka Sejahtera Engineering', Jurnal Manajemen Bisnis Petra, 1.2 (2013)

Fadriati, Model Total Quality Management Pada Lembaga Pendidikan Islam, International Conference on Education (IAN Batusangkar, 2018)

Fitriani, 'Proses Perencanaan Total Quality Management Dalam Pendidikan Islam', Jurnal Kependidikan, 11.2 (2017)

Hadi, Sutrisno, Metodologi Reseach (Yogyakarta: andi Offiset, 1994)

Handoko, T. Hani, Manajemen Sumber Daya Manusia, BPFE (Yogyakarta, 1996)

Haryadi, Vika Luila dan Bambang, ', Pengembangan Fungsi Manajemen Sumber Daya

Manusia Pada PT. Ageless Aesthetic Clinic', Jurnal Agora, 1.3 (2013)

Hasibuan, Melayu SP., Manajemen Sumber Daya Manusia (Jakarta: PT Bumi Aksara, 2007)

Jurdi, Fatahullah, Manajemen Sumber Daya Manusia Strategi Pengelolaan SDM Berkualitas Dan Berdaya Saing (Malang: Intrans Publishing, 2018)

Kalangi, Roosje, 'Pengembangan Sumber Daya Manusia Dan Kinerja Aparat Sipil

Negara Di Kabupaten Kepulauan Sangihe Provinsi Sulawesi Utara', Jurnal LPPM Bidang EkoSosBudKum, 2.1 (2015)

Kementerian Pendidikan Nasional, Dirjen Peningkatan Mutu Pendidik dan Tenaga Kependidikan (PMPTK), Direktorat Tenaga Kependidikan Penilaian Kinerja Guru Dan Kompetensi Evaluasi Pendidikan, 2008

Lisa Nilhuda, Hade Afriansyah, dan Rusdinal, Manfaat Total Quality Management Dalam Meningkatkan Kualitas Pendidikan Di Indonesia, Manajemen Mutu Terpadu (Padang, 2019)

Menengah, Direktorat Jenderal Pendidikan Dasar dan, Petunjuk Pelaksanaan 
Penjaminan Mutu Pendidikan Oleh Satuan Pendidikan, Kementerian Pendidikan Dan Kebudayaan, 2016

Munir, Miftakhul, 'Keberadaan Total Quality Management Dalam Lembaga Pendidikan (Antara Prinsip Implementasi Dan Pilar Tqm Dalam Pendidikan)', Jurnal Realita, 16.1 (2018), 1-21

Nilam Sari dan Abrar Amri, 'Peran Sumber Daya Manusia (SDM) Dalam Perkembangan Perbankan Syariah: Analisis Kerja Dan Kinerja Pegawai', Jurnal Wacana Hukum Islam Dan Kemanusiaan, 18.2 (2018)

Rahmawati, Ika Dewi, Manajemen Sumber Daya Manusia Dalam Peningkatan Kualitas Sekolah, Naskah Publikasi, Fakultas Agama Islam Universitas Muhammadiya (Surakarta, 2012)

Rohmat, 'Model Manajemen Mutu Madrasah Kajian Di MIN Dan MI Ma'arif Pageraji Purwokerto, JPA', 19.1

Rusmini, 'Peningkatan Mutu Sumber Daya Manusia Melalui Pendidikan Karakter Dan Attitude', Jurnal Nur El-Islam, 4.2 (2017)

Sallis, Edward, Total Quality Management in Education: Manajemen Mutu Pendidikan (Yogyakarta: IRCiSoD, 2012)

Saputra, Wali, 'Upaya Pengembangan Total Quality Management Pada Masyarakat Pelaku Bisnis (Studi Komparatif Manajemen Konvensional Dan Syariah)', Jurnal Kewirausahaan, 13.9 (2014), 249-73

Sedarmayanti, Sumber Daya Manusia Produktivitas Kerja (Bandung: CV Mandar Maju, 2001)

Siagian, Sondang P., Manajemen Sumber Daya Manusia (Jakarta: PT Bumi Aksara, 2016)

Sudadio, 'Peningkatan Mutu Pendidikan Dasar Dan Menengah Di Provinsi Banten Melalui Manajemen Berbasis Sekolah', Jurnal Penelitian Dan Evaluasi Pendidikan, 16.2 (2012)

Suparto, 'Manajemen Sumber Daya Manusia (SDM) Guru Dalam Peningkatan Mutu Pendidikan Di Madrasah Ibtidaiyah Al-Islam Kota Bengkulu', Jurnal Manajemen Pendidikan Islam., 1.3 (2016)

Supriyatno, Marno dan Triyo, Manajemen Dan Kemepemimpinan Islam (Bandung: Refika Aditama, 2008)

Sutrisno, Edy, Manajemen Sumber Daya Manusia (Jakarta: Kencana, 2010)

Tahir, H. Abd. Wahid, 'Pengembangan Manajemen Sumber Daya Manusia Terhadap Peningkatan Mutu Pendidikan', 1.1 (2017)

Walidin, W, 'Arah Pengembangan Sumber Daya Manusia Dalam Dimensi Pendidikan Islam', Jurnal Edukasi, 2.2 (2016)

Widiansyah, A, Peranan Sumber Daya Pendidikan Sebagai Faktor Penentu Dalam Manajemen Sistem Pendidikan (Cakrawala, 2018) 